\title{
EFEK COLD PRESSOR TEST TERHADAP PASOKAN DAN KEBUTUHAN OKSIGEN MIOKARD PADA PEROKOK AKTIF DI KECAMATAN UNGARAN KABUPATEN SEMARANG
}

\author{
Gipta Galih Widodo*, Elly Nurachmah**, Budiharto***
}

\begin{abstract}
Abstrak
Penelitian kuasi eksperimen ini bertujuan menguji pengaruh cold pressor test (CPT) terhadap pasokan dan kebutuhan oksigen miokard pada perokok aktif dengan pengukuran tekanan darah dan segmen ST di Kecamatan Ungaran Kabupaten Semarang. Jumlah sampel dalam penelitian ini sebanyak 76 perokok aktif di Kecamatan Ungaran Kabupaten Semarang dan ditentukan dengan cluster sampling. Pengaruh CPT terhadap tekanan darah dan segmen ST pada perokok aktif diuji dengan dependent sample t test. Hasil penelitian menunjukkan rerata tekanan darah setelah intervensi CPT mengalami penurunan. Hasil analisis dengan uji $t$ test menunjukkan bahwa CPT menurunkan tekanan darah setelah intervensi CPT ( $\mathrm{p}=0,000)$. Rata-rata segmen ST sebelum dan setelah intervensi CPT tidak jauh berbeda. Hasil uji $t$ test menunjukkan bahwa CPT tidak berpengaruh dalam menurunkan segmen ST pada perokok aktif $(\mathrm{p}=0,895)$. Penelitian ini menyimpulkan bahwa CPT berpengaruh terhadap perubahan tekanan darah pada perokok aktif tetapi tidak berpengaruh terhadap perubahan segmen ST. Selama CPT terjadi peningkatan tekanan darah dan berangsur menurun setelah dilakukan CPT. Segmen ST tidak mengalami perubahan. CPT dapat digunakan oleh perawat untuk memprediksi kejadian peningkatan tekanan darah. Untuk penelitian selanjutnya sebaiknya digunakan alat ukur yang lebih sensitif dan menggunakan determinan pasokan dan kebutuhan oksigen miokard yang lain seperti preload dan denyut jantung.
\end{abstract}

Kata kunci: cold pressor test, perokok aktif, segmen ST, dan tekanan darah

\section{Abstract}

This quasy-experimental research was aimed to examine the effect of cold pressor test (CPT) to the myocardial oxygen demand and supply among active smokers in the Ungaran district, Semarang by measuring blood pressure and ST segment. There were 76 active smoker males involved as the cluster sampling in the research. To examine the CPT effect on the blood pressure and ST segment among the active smokers, dependent sample t test was conducted. The result of the research showed that average blood pressure is decreased after CPT. Furthermore, CPT showed its effects on decreasing blood pressure after the intervention $(p=0,000)$. The averages of ST segment before and after intervention of CPT were slightly different. Thus, CPT indicated no significant impact in decreasing ST segment among active smokers $(p=0,895)$. The research concluded that CPT caused blood pressure changes among active smokers but do not have effect in ST segment changes. On the other hand, it was observed that the initial blood pressure were increase during CPT but then gradually decreased immediately after the end of CPT. In addition, ST segment remained unchanged. Therefore, the CPT is still beneficial for predicting high blood pressure in patient compared to other cardiac stress test. Nevertheless, it is recommended to use more sensitive device and to consider other determinants of the myocardial oxygen demand and supply such as preload and heart beat for further research.

Key words: active smokers, blood pressure, cold pressor test, and ST segment

\section{LATAR BELAKANG}

Penyakit jantung koroner merupakan penyakit kardiovaskuler yang sering terjadi di masyarakat. Ada beberapa faktor risiko yang dapat menjadi penyebab penyakit jantung koroner dan hipertensi. Faktor-faktor tersebut dibagi dalam faktor yang tidak dapat dimodifikasi dan faktor yang dapat dimodifikasi. Keturunan, ras, umur, dan jenis kelamin termasuk faktor yang tidak dapat dimodifikasi, sedangkan kebiasaan merokok, hipertensi, peningkatan serum kolesterol, diabetes mellitus, tidak beraktifitas, dan kegemukan dapat dimodifikasi. Selain itu, terdapat faktor pendukung penyakit jantung koroner yaitu stres, menopause, dan respon terhadap inflamasi. 
Merokok menjadi faktor utama penyebab penyakit pembuluh darah jantung atau penyakit jantung koroner. Kematian akibat jantung koroner $70 \%$ lebih tinggi terjadi pada perokok dibandingkan orang yang tidak merokok (Black \& Hawk, 2005). Data memperkirakan bahwa 59\% pria berusia di atas 10 tahun di Indonesia telah menjadi perokok harian. Kematian akibat sakit yang ditimbulkan rokok per tahun mencapai 58 ribu orang. Ironisnya 60 persen dari jumlah perokok di Indonesia berasal dari kalangan miskin dan menengah (Depkes, 2005).

Pemeriksaan diagnostik yang dapat dilakukan pada klien untuk mengetahui dan memprediksi gangguan kardiovaskuler adalah dengan memberikan beban pada jantung. Ada dua metode untuk memberikan beban pada jantung. Pertama dengan menggunakan latihan yaitu isotonik (treadmill dan bycycle ergometry) dan isometrik (handgrip). Kedua, tanpa menggunakan latihan yaitu dengan menggunakan obat (dobutamine, dipyridamole, adenosine dan arbutamine), peningkatan afterload (cold pressor test dan hiperventilasi (Tak \& Giuterrez, 2004).

Cold Pressor Test (CPT) adalah uji beban jantung dengan cara mencelupkan salah satu tangan ke dalam air es selama dua menit tanpa diangkat untuk melihat kenaikan tekanan darah akut sebagai perlawanan terhadap ejeksi dari ventrikel kiri dalam sistem arteri sistemik yang berakibat terjadinya peningkatan akut dari afterload (Dictinarybarn, 1998). CPT diyakini dapat meningkatkan kebutuhan oksigen miokard dengan peningkatan afterload yang dapat memprovokasi terjadinya iskemia dan angina atau nyeri dada. Denyut jantung dan tekanan darah berkorelasi baik terhadap kebutuhan oksigen puncak. Namun, perlu diketahui bahwa CPT dapat memprovokasi terjadinya angina secara bermakna pada pasien-pasien dengan penyakit jantung koroner (Gray et al., 2002).

CPT merupakan metode yang sederhana dan murah untuk mengetahui risiko gangguan kardiovaskuler. Apalagi jika respon dari CPT diukur dengan menggunakan elektrokardiogram
(EKG) dan pengukuran tekanan darah. Hal ini tentu akan menurunkan biaya yang harus dikeluarkan oleh pasien. Penelitian tentang respon pembuluh darah arteri terhadap CPT pada pasien prehipertensi ditemukan bahwa CPT dapat menurunkan pengembangan arteri karotis dan brakialis. Selain itu, CPT dapat menurunkan kekuatan tekanan nadi pada prehipertensi (Lafleche et al.,1998).

Nitenberg et al (2004) melakukan penelitian tentang prognosis nilai penyempitan arteri koroner dengan CPT pada pasien diabetes mellitus tipe 2 dengan gambaran angiografi normal dan tanpa faktor risiko. Penelitian ini menyimpulkan bahwa CPT dapat digunakan untuk memprediksi kejadian gangguan kardiovaskuler pada jangka waktu yang lama pada klien dengan DM tipe 2. Acuan dari penelitian ini adalah terjadinya penyempitan arteri koroner.

\section{METODOLOGI}

Metode penelitian ini menggunakan desain kuasi eksperimen dengan control-group pretestposttest design. Sumber data adalah data primer yang diperoleh dari pengisian kuisioner, pemeriksaan tekanan darah dan EKG. Jumlah sampel 76 responden (38 responden kelompok intervensi dan 38 responden kelompok kontrol) dipilih secara cluster sampling dengan kriteria inklusi yaitu: bersedia diteliti, laki-laki berusia 1545 tahun, perokok aktif, tidak memiliki masalah kesehatan yang mengganggu sistem kardiovaskuler seperti penyakit jantung, infark miokard, dan disritmia. Instrumen yang digunakan dalam penelitian adalah kuisioner identitas responden, prosedur pelaksanaan cold pressor test, spigmomanometer, dan EKG.

Pengumpulan data dilakukan dalam dua tahap: a) tahap pertama sebelum intervensi CPT. Pemeriksaan tekanan darah dilakukan tiga kali untuk menentukan tekanan darah basal kemudian dilanjutkan dengan pemeriksaan EKG baik pada kelompok intervensi maupun kontrol, b) tahap kedua setelah intervensi CPT. 
Pengukuran tekanan darah dilakukan segera setelah pengangkatan tangan dari rendaman air es dilanjutkan dengan pemeriksaan EKG pada kelompok intervensi. Sedangkan pada kelompok kontrol pengukuran tekanan darah dan pemeriksaan EKG dilakukan setelah 2 menit dari pemeriksaan pertama.

Pengukuran tekanan darah juga dilakukan pada saat perendaman tangan pada air es pada menit pertama. Hal ini dilakukan untuk mengontrol peningkatan tekanan darah yang terlalu tinggi yang dapat membahayakan responden. Setelah perendaman, tangan responden dikeringkan dengan handuk tebal untuk menghindari cedera pada responden.

\section{HASIL PENELITIAN}

Hasil analisis didapatkan rerata usia perokok aktif pada kelompok intervensi adalah 33,26 tahun (95\% CI: 30,96-35,57), median 34,50 dengan standar deviasi 7,005. Usia termuda 21 tahun dan usia tertua 45 tahun. Hasil estimasi interval menyimpulkan 95\% diyakini bahwa rerata usia perokok aktif adalah 30,96 tahun sampai dengan 35,57 tahun. Sebagian besar responden tidak memiliki riwayat keturunan dengan hipertensi yaitu sebanyak $77,63 \%$ dan sisanya memiliki riwayat keturunan dengan hipertensi. Selain itu, sebagian besar responden tidak melakukan aktifitas fisik atau olah raga teratur yaitu sebesar $61,84 \%$ sedangkan sisanya melakukan aktifitas fisik atau olah raga secara teratur.

Rerata nilai tekanan darah pada kelompok intervensi sebelum CPT adalah 118,16 mmHg dengan standar deviasi 11,115 mmHg. Pengukuran sesudah CPT didapat rerata tekanan darah adalah $113,16 \mathrm{mmHg}$ dengan standar deviasi 10,425 mmHg. Hasil uji statistik beda dua mean untuk dua sampel berpasangan (paired t-test) menunjukkan adanya perbedaan rerata nilai tekanan darah yang bermakna dengan nilai $p=0,000$. Hal ini diperkuat dengan hasil selisih rerata tekanan darah sebelum dan sesudah CPT yang menunjukkan penurunan 5 mmHg dengan standar deviasi 7,970 $\mathrm{mmHg}$.
Rerata nilai tekanan darah pada kelompok kontrol sebelum CPT adalah 116,84 mmHg dengan standar deviasi 13,578 mmHg. Pengukuran sesudah CPT didapat rerata tekanan darah $116,05 \mathrm{mmHg}$ dengan standar deviasi 14,054 mmHg. Hasil uji statistik beda dua mean untuk dua sampel berpasangan (paired t-test) menunjukkan adanya perbedaan rerata nilai tekanan darah yang tidak bermakna dengan nilai $\mathrm{p}=0,83$, dengan kata lain tidak perbedaan nilai rerata tekanan darah sebelum dan sesudah intervensi pada kelompok kontrol.

Rerata nilai segmen ST pada kelompok intervensi sebelum CPT adalah 1,487 mm dengan standar deviasi 0,472 mm. Pengukuran sesudah CPT didapatkan rerata nilai segmen ST adalah 1,5 mm dengan standar deviasi 0,465 mm. Hasil uji statistik beda dua mean untuk dua sampel berpasangan (paired t-test) menunjukkan tidak ada perbedaan rerata nilai segmen ST yang bermakna sebelum dan sesudah dilakukan CPT dengan nilai $\mathrm{p}=0,895$. Hal ini diperkuat dengan hasil selisih rerata nilai segmen ST sebelum dan sesudah CPT yang menunjukkan perubahan yang sangat kecil yaitu $0,013 \mathrm{~mm}$ dengan standar deviasi $0,6095 \mathrm{~mm}$.

Rerata nilai segmen ST pada kelompok kontrol sebelum CPT adalah 1,461 mm dengan standar deviasi 0,4408 mm. Pengukuran sesudah CPT didapatkan rerata nilai segmen ST adalah 1,461 mm dengan standar deviasi 0,4252 $\mathrm{mm}$. Hasil uji statistik beda dua mean untuk dua sampel berpasangan (paired $t$-test) menunjukkan tidak ada perbedaan rerata nilai segmen ST yang bermakna sebelum dan sesudah dilakukan CPT dengan nilai $\mathrm{p}=1,00$. Hal ini diperkuat dengan tidak adanya selisih rerata segmen ST sebelum dan sesudah CPT.

\section{PEMBAHASAN}

Penelitian ini menunjukkan bahwa cold pressor test berpengaruh dalam menurunkan tekanan darah setelah intervensi CPT $(\mathrm{p}=0,000)$. Peneliti melakukan pengukuran tekanan darah pada menit pertama selama perendaman pada air es untuk menghindari hiperaktifitas yang tidak terkontrol selama prosedur uji beban jantung. 
Hal ini merupakan salah satu kode etik yang harus dilakukan oleh peneliti untuk menghindari cidera pada responden. Pengukuran tekanan darah selama perendaman menunjukkan hasil rerata tekanan responden mengalami kenaikan.

Karhonen (2006) menyatakan bahwa peningkatan tekanan darah selama uji beban jantung dengan menggunakan CPT disebabkan oleh beberapa faktor yaitu peningkatan aktifitas sistem saraf simpatis, vasokontriksi, dan perasaan nyeri selama intervensi perendaman tangan ke dalam air es. Peningkatan aktifitas sistem saraf simpatis dapat meyebabkan peningkatan kecepatan denyut jantung dan volume sekuncup disertai dengan vasokontriksi pembuluh darah arteriol dan vena. Perubahan ini menyebabkan peningkatan curah jantung dan resistensi perifer total sehingga tekanan darah meningkat (Sherwood, 1996). Menurut Black dan Jacobs (1997) tekanan darah dipengaruhi oleh dua faktor utama yaitu aliran darah dan tahanan perifer vaskuler. Masing-masing faktor dipengaruhi oleh hal yang berbeda. Aliran darah tubuh dipengaruhi oleh curah jantung, denyut jantung, dan volume darah itu sendiri. Sedangkan tahanan perifer vaskuler dipengaruhi oleh elastisitas pembuluh darah, penyempitan pembuluh darah, dan viskositas darah.

Rangsang dingin akibat dicelupkannya tangan ke dalam air es menimbulkan stimulus pada saraf simpatis jantung. Stimulus tersebut menyebabkan peningkatan norepineprin dan epineprin secara signifikan. Kedua zat ini berinteraksi dengan reseptor tipe alfa adrenergik menyebabkan vasokontriksi pembuluh darah termasuk pembuluh darah koroner (Frank, 2004).

Vasokontriksi pembuluh darah menyebabkan peningkatan resistensi perifer total yang berakibat kejadian pergeseran tekanan darah ke nilai di atas normal atau meningkat. Interaksi katekolamin dengan reseptor beta adrenergik dapat menyebabkan peningkatan denyut jantung, konduksi nodus AV dan kontraktilitas miokard yang berakibat peningkatan curah jantung dan tekanan darah (Black \& Hawk, 2005).
Faktor lain yang menyebabkan peningkatan tekanan darah pada CPT selain stimulus sistem saraf simpatis dan vasokontriksi pembuluh darah adalah rangsang nyeri selama perendaman air es. Nyeri merupakan stimulus yang kuat untuk dapat meningkatkan tekanan darah. Menurut Morton et al (2005) nyeri menyebabkan rangsangan terhadap sistem saraf otonom yang dapat menyebabkan vasokontriksi, peningkatan denyut jantung, dan kontraktilitas jantung sehingga terjadi peningkatan tekanan darah, nadi, dan curah jantung. Peningkatan kerja miokard dan penggunaan oksigen dapat menyebabkan terjadinya iskemia miokard.

Perendaman tangan ke dalam air es dapat dikatakan sebagai stressor bagi tubuh. Setiap tubuh mendapat stressor akan memberikan suatu respon, sesuai dengan teori general adaptation sydrome menurut Selye. Menurut Selye dalam Black dan Jacobs (1997), setiap stressor fisik maupun psikis dapat menyebabkan rangsangan pada sistem limbik dan hipotalamus sehinga terjadi pengeluaran katekolamin oleh medula adrenal. Pengeluaran katekolamin ini menyebabkan peningkatan kerja jantung yang berakibat terjadi peningkatan tekanan darah dan denyut jantung. Selain itu, katekolamin dapat menyebabkan peningkatan asupan oksigen.

Konsumsi oksigen miokard sangat ditentukan oleh denyut jantung, preload, afterload, dan kontraktilitas miokard. Perubahan tekanan darah dapat digunakan sebagai indikator perubahan afterload (Gray et al., 2002). Menurut Klabunde (2007), peningkatan afterload dapat meningkatkan kebutuhan oksigen miokard karena peningkatan tekanan darah. Begitu juga dengan peningkatan preload (ventricular end-diastolic volume) dapat menyebabkan peningkatan kebutuhan oksigen miokard. Artinya peningkatan tekanan darah atau afterload pada saat uji beban jantung dapat menyebabkan kebutuhan oksigen miokard meningkat. Kondisi ini dapat memicu terjadinya iskemia karena terjadi ketidakseimbangan antara pasokan dan kebutuhan oksigen miokard.

Keluhan rasa nyeri memang terjadi pada saat tangan responden dicelupkan ke dalam air es. 
Rasa nyeri berangsur menghilang setelah tangan diangkat dari air es dan tangan dibungkus dengan handuk tebal dan tangan dikeringkan dengan handuk tersebut.

Hasil penelitian ini juga menunjukkan bahwa terjadi penurunan tekanan darah setelah intervensi perendaman pada air es selama dua menit. Hal ini disebabkan karena faktor yang menjadi penyebab terjadinya peningkatan darah pada intervensi CPT telah dihilangkan yaitu dengan mengangkat tangan responden dari air es kemudian mengeringkan tangan tersebut dengan handuk tebal. Dengan demikian stimulus sistem saraf simpatis, vasokontriksi pembuluh darah dan nyeri akibat CPT tidak ada sehingga terjadi penurunan tekanan darah. Akan tetapi, penurunan ini lebih rendah dari tekanan darah sebelum intervensi. Hal ini mungkin disebabkan karena pada saat pemeriksaan awal responden mengalami kecemasan dan kecemasan tersebut berangsur menurun setelah prosedur CPT selesai dilakukan.

Salah satu faktor ikut mengatur tekanan darah yaitu pengontrolan suhu. Kontrol hipotalamus terhadap arteriol kulit untuk mengatur suhu harus didahulukan daripada kontrol pusat kardiovaskuler terhadap pembuluh darah tersebut untuk mengatur tekanan darah. Akibatnya, tekanan darah dapat turun pada saat pembuluh kulit mengalami dilatasi menyeluruh untuk mengeluarkan panas dari tubuh, walaupun respons baroreseptor memerintahkan vasokontriksi kulit untuk mempertahankan resistensi perifer total yang adekuat (Sherwood, 1996).

Rerata nilai segmen ST pada kelompok intervensi sebelum CPT adalah 1,487 mm dengan standar deviasi 0,472 mm. Pengukuran sesudah CPT didapatkan rerata nilai segmen $\mathrm{ST}$ adalah 1,5 mm dengan standar deviasi 0,465 mm. Hasil uji statistik beda dua mean untuk dua sampel berpasangan (paired t-test) menunjukkan tidak ada perbedaan rerata nilai segmen ST yang bermakna sebelum dan sesudah dilakukan CPT dengan nilai $\mathrm{p}=0,895$. Hal ini diperkuat dengan hasil selisih rerata nilai segmen ST sebelum dan sesudah CPT yang menunjukkan perubahan yang sangat kecil yaitu 0,013 mm dengan standar deviasi 0,6095 $\mathrm{mm}$. Hasil penelitian menunjukkan bahwa cold pressor test tidak memberikan pengaruh yang signifikan terhadap perubahan segmen ST pada perokok aktif dengan nilai $\mathrm{p}=0,895$.

Penelitian Yoshida et al (1999) menunjukkan bahwa CPT memiliki kemampuan yang sama dengan mental stress dalam menginduksi vasospasme pada serangan angina. CPT dapat merubah gambaran depresi segmen $\mathrm{ST}$ pada pasien dengan angina pektoris. Hal ini didukung oleh pendapat Waters (1986), CPT dapat memicu terjadinya ST elevasi tetapi sangat kecil dibandingkan dengan latihan dan penggunaan ergonovine test.

Rilantono (1996) menjelaskan bahwa bila arteri koroner mengalami gangguan penyempitan atau sumbatan, pasokan oksigen arteri koroner tidak mencukupi kebutuhan sehingga terjadi ketidakseimbangan antara pasokan dan kebutuhan oksigen miokard yang mana hal ini akan menimbulkan gangguan. Manifestasi gangguan tergantung kepada berat ringannya penyempitan dan luas daerah yang terkena. Dalam keadaan istirahat, meskipun arteri koroner mengalami penyempitan $60 \%$ belum menimbulkan gejala, sebab aliran darah koroner masih mencukupi kebutuhan jaringan. Apabila dilakukan uji beban jantung sehingga terjadi peningkatan kebutuhan oksigen miokard maka aliran yang tadinya cukup menjadi berkurang sehingga terjadi hipoksia jaringan miokard dan jika berlanjut akan terjadi iskemia dan nyeri dada.

Hasil penelitian ini bukan berarti CPT tidak berpengaruh terhadap segmen ST tetapi CPT tidak mempengaruhi terjadinya perubahan segmen ST pada perokok aktif setelah dilakukan intervensi CPT. CPT akan memberikan pengaruh ketidakseimbangan pasokan dan kebutuhan oksigen miokard dengan gambaran depresi segmen ST pada pasien dengan penyakit jantung koroner. Tidak adanya pengaruh CPT terhadap segmen ST pada perokok aktif disebabkan responden pada penelitian ini adalah para perokok aktif yang tidak memiliki riwayat penyakit jantung koroner. 
sebelum dilakukan intervensi CPT, responden dikaji terlebih dahulu terhadap adanya kemungkinan depresi segmen ST, dari seluruh responden kelompok intervensi tidak ada yang mengalami depresi segmen ST.

\section{KESIMPULAN}

Cold pressor test (CPT) dapat menurunkan tekanan darah pada perokok aktif. CPT tidak dapat menurunkan segmen ST pada perokok aktif. Artinya CPT tidak berpengaruh terhadap pasokan dan kebutuhan oksigen miokard pada perokok aktif. Responden dalam penelitian ini berusia antara 20-45 tahun dan tidak memiliki riwayat PJK. CPT dapat memprovokasi terjadinya angina pada kondisi PJK dan pada kejadian PJK lebih banyak terjadi pada usia diatas 50 tahun atau lanjut usia.

Perawat spesialis keperawatan medikal bedah dapat melakukan deteksi dini risiko PJK dengan menggunakan CPT dan pengukuran tekanan darah atau pengukuran tanda vital yang lain di masyarakat ataupun di tatanan pelayanan rumah sakit misalnya di poliklinik secara mandiri. Perlu dilakukan pemeriksaan secara berkala pada perokok aktif berkaitan dengan kondisi kesehatan jantung khususnya dengan menggunakan pemeriksaan CPT dan tekanan darah oleh perawat atau tenaga kesehatan lainnya untuk mendeteksi dini risiko terjadinya hipertensi dan penyakit jantung koroner.

Program pendidikan kesehatan tentang bahaya rokok terhadap kesehatan jantung dan cara hidup sehat untuk mencegah terjadinya hipertensi dan penyakit jantung koroner perlu dibuat secara terencana, terarah, dan berkesinambungan. Perawat perlu melibatkan peran serta masyarakat dalam memberikan informasi tentang bahaya rokok terhadap kesehatan jantung seperti tokoh masyarakat, tokoh agama, dan pejabat pemerintah.

Rekomendasi untuk penelitian selanjutnya disarankan dapat digunakan determinan lain untuk mengetahui pasokan dan kebutuhan oksigen miokard. Determinan yang mempengaruhi kebutuhan oksigen miokard tidak hanya afterload yang linier dengan tekanan darah tetapi juga dipengaruhi oleh kontraktilitas, denyut jantung, dan preload. Alat ukur sebaiknya gunakan alat yang memiliki sensitifitas lebih tinggi seperti ekokardiografi atau Positron Emission Tomography (PET).

Rentang usia responden sebaiknya tidak dibatasi pada usia 15-45 tahun tetapi diperluas sampai dengan usia lanjut. Penelitian tentang jenis rokok, lama merokok, dan jumlah konsumsi rokok terhadap efek vasokontriksi pembuluh darah perlu dilakukan. Sebaiknya digunakan metode uji beban jantung yang lain seperti treadmill atau dypiridamol sebagai pembanding untuk menguji sensitifitas CPT. Semua faktor risiko penyakit jantung koroner diteliti untuk mengetahui faktor risiko yang lebih berkontribusi terhadap perubahan tekanan darah dan segmen ST (YA, JH).
* Staf Akademik Keperawatan Medikal Bedah PSIK STIKES Ngudi Waluyo
** Staf Akademik Keperawatan Medikal Bedah FIK UI
*** Staf Akademik FKM UI

\section{KEPUSTAKAAN}

Black, J.M., \& Hawk, J.H. (2005). Medical surgical nursing: Clinical management for positive outcome. St. Louis: Elsevier Saunders.

Black, J.M., \& Jacobs, E.M. (2005). Medical surgical nursing: Clinical management for continuity of care. 5th ed. Philadelphia: W.B. Saunders Company.

Depkes. (2005). Pemerintah berupaya turunkan konsumsi rokok. http://www.ditjenfaralkes .depkes.go, diperoleh 30 Januari 2007.

Dictinarybarn. (1998). Cold pressor test. http:// www.dictionarybarn.com, diperoleh 30 Januari 2007.

Frank, S.M. (2004). Pathophysiology and consequences hypothermia. http:// www.comcast.net, diperoleh 25 Januari 2007. 
Gray, H.H., Dawkins, K.D., Morgan, J.M., \& Simpson, I.A. (2002). Lecture notes: kardiologi. Edisi 4. Alih bahasa: Azwar Agoes \& Asri Dwi Rachmawati. Jakarta: Erlangga.

Karhonen, I. (2006). Blood pressure and heart rate responses in men exposed to arm and leg cold pressor tests and whole-body cold exposure. http://www.ijch.oulu.fi., diperoleh 21 Juni 2007.

Klabunde, R.E. (2007). Determinants of myocardial oxygen consumption. http://www. cvpharmacology.com, diperoleh 21 Juni 2007)

Lafleche, A.B., Pannier, B.M., Laloux, B., \& Safar, M.E. (1998). Arterial response during cold pressor test in borderline hypertension. http://www.medscape.com, diperoleh 20 Januari 2007.

Nitenberg, A., et al. (2004). Prognostic value of epicardial coronary artery constriction to the cold pressor test in type 2 diabetic patiens with angiographically normal coronary arteries and no other major coronary risk factors. http:/ /www.pubmed.com, diperoleh 18 Januari 2007.

Rilantono. (1996). Buku ajar kardiologi. Jakarta: FKUI.

Sherwood, L. (1996). Fisiologi manusia: dari sel ke sistem. Alih bahasa: B. U. Pendit. Jakarta: EGC.

Tak, T. \& Giuterrez, R. (2004). Comparing stress testing methods. http://www.postgraduate. med.com, diperoleh 6 Februari 2007.

Waters, D.D. (1986). Problems to the detection of myocardial ischemia caused by coronary vasospasm. http: www.emory.edu, diperoleh 10 Juli 2007.

Yoshida, K., et al. (1999). Mental stress test in an effective inducer of vasospatic angina pectoris: comparison with cold pressor test, hyperventilation and: master two-step exercise test. http: www.emory.edu, diperoleh 10 Juli 2007. 